\title{
Late Miocene to early Pliocene biofacies of Wanganui and Taranaki Basins, New Zealand: applications to paleoenvironmental and sequence stratigraphic analysis
}

\author{
AUSTIN J. W. HENDY* \\ PETER J. J. KAMP \\ Department of Earth Sciences \\ The University of Waikato \\ Private Bag 3105 \\ Hamilton, New Zealand \\ email: hendya@email.uc.edu \\ *Present address: Department of Geology, University of \\ Cincinnati, Cincinnati, OH 45221-0013, USA.
}

\begin{abstract}
The Matemateaonga Formation is late Miocene to early Pliocene (upper Tongaporutuan to lower Opoitian New Zealand Stages) in age. The formation comprises chiefly shellbeds, siliciclastic sandstone, and siltstone units and to a lesser extent non-marine and shallow marine conglomerate and rare paralic facies. The Matemateaonga Formation accumulated chiefly in shelf paleoenvironments during basement onlap and progradation of a late Miocene to early Pliocene continental margin wedge in the Wanganui and Taranaki Basins. The formation is strongly cyclothemic, being characterised by recurrent vertically stacked facies successions, bounded by sequence boundaries. These facies accumulated in a range of shoreface to mid-outer shelf paleoenvironments during conditions of successively oscillating sea level. This sequential repetition of facies and the biofacies they enclose are the result of sixth-order glacio-eustatic cyclicity. Macrofaunal associations have been identified from statistical analysis of macrofossil occurrences collected from multiple sequences. Each association is restricted to particular lithofacies and stratal positions and shows a consistent order and/or position within the sequences. This pattern of temporal paleoecologic change appears to be the result of lateral, facies-related shifting of broad biofacies belts, or habitat-tracking, in response to fluctuations of relative sea level, sediment flux, and other associated paleoenvironmental variables. The associations also show strong similarity in terms of their generic composition to biofacies identified in younger sedimentary strata and the modern marine benthic environment in New Zealand.
\end{abstract}

Keywords Wanganui Basin; Taranaki Basin; Miocene; Pliocene; Tongaporutuan; Kapitean; Opoitian; Matemateaonga Formation; biofacies; paleoecology; paleoenvironments; sequence stratigraphy

\section{INTRODUCTION}

The Matemateaonga Formation is a thick (c. 1000-2000 m) and extensive shelf succession that crops out in Wanganui Basin and onshore in Taranaki Basin in the eastern part of the Taranaki Peninsula (Vonk et al. 2002; Kamp et al. 2004, this issue). It provides an excellent setting for description of the macrofaunal paleoecology of late Miocene to early Pliocene New Zealand shelfal macrofauna across a wide range of paleoenvironments and lithofacies. While biofacies have been identified from Waipipian (Jones 1967; Whitten 1973), Nukumaruan (Fleming 1953), Castlecliffian (Fleming 1953; Abbott \& Carter 1997), and Haweran (Grace 1974) shelf sediments, similar paleoenvironments in the Tongaporutuan and Kapitean Stages are poorly described in New Zealand (Beu et al. 1990), and accordingly little is known of benthic community composition during this time. Shallow marine facies of Opoitian age are far more extensive in New Zealand sedimentary basins, but the limited paleoecologic information that is available for this stage remains anecdotal in form, with the exception of early studies such as Marwick (1948), Laws (1950), and a more rigorous paleoecological analysis by Spratt (1974) for assemblages of the Kaawa Formation, southwest Auckland.

Understanding the spectrum and environmental preferences of biofacies within Matemateaonga sequences enables the magnitudes and rates of paleoenvironmental change to be qualitatively estimated (e.g., change in water depth within particular systems tracts of sequences). Furthermore, the characterisation of biotic responses to inferred sea-level oscillations during this time provides the opportunity to make comparisons with similar data from the younger (Waipipian-Castlecliffian) shelf cyclothemic successions in Wanganui Basin (e.g., Abbott \& Carter 1997). Such a comparison can reveal subtle variations in sedimentologic and hydrologic conditions associated with changing regional paleogeography and shifts in frequency of glacio-eustatic sealevel change in a single sedimentary basin.

\section{STRATIGRAPHIC SETTING}

The Matemateaonga Formation crops out extensively in an east-west-trending belt from eastern Taranaki Peninsula through the central North Island to the Ruahine and Kaimanawa Ranges (Fig. 1) (Vonk et al. 2002; Kamp et al. 2004). West of Waiouru and beneath Taranaki Peninsula the formation conformably overlies older (Miocene) formations, whereas east of Waiouru it onlaps basement, as it does beneath substantial parts of the northern half of Wanganui Basin. The lower contact of the Matemateaonga Formation is strongly diachronous, ranging from upper Tongaporutuan to lower Opoitian (constrained through biostratigraphy), reflecting a general southward-directed onlap of basement and a northward transition into contemporary slope deposits of the Kiore and Urenui Formations (Kamp et al. 2004). These 


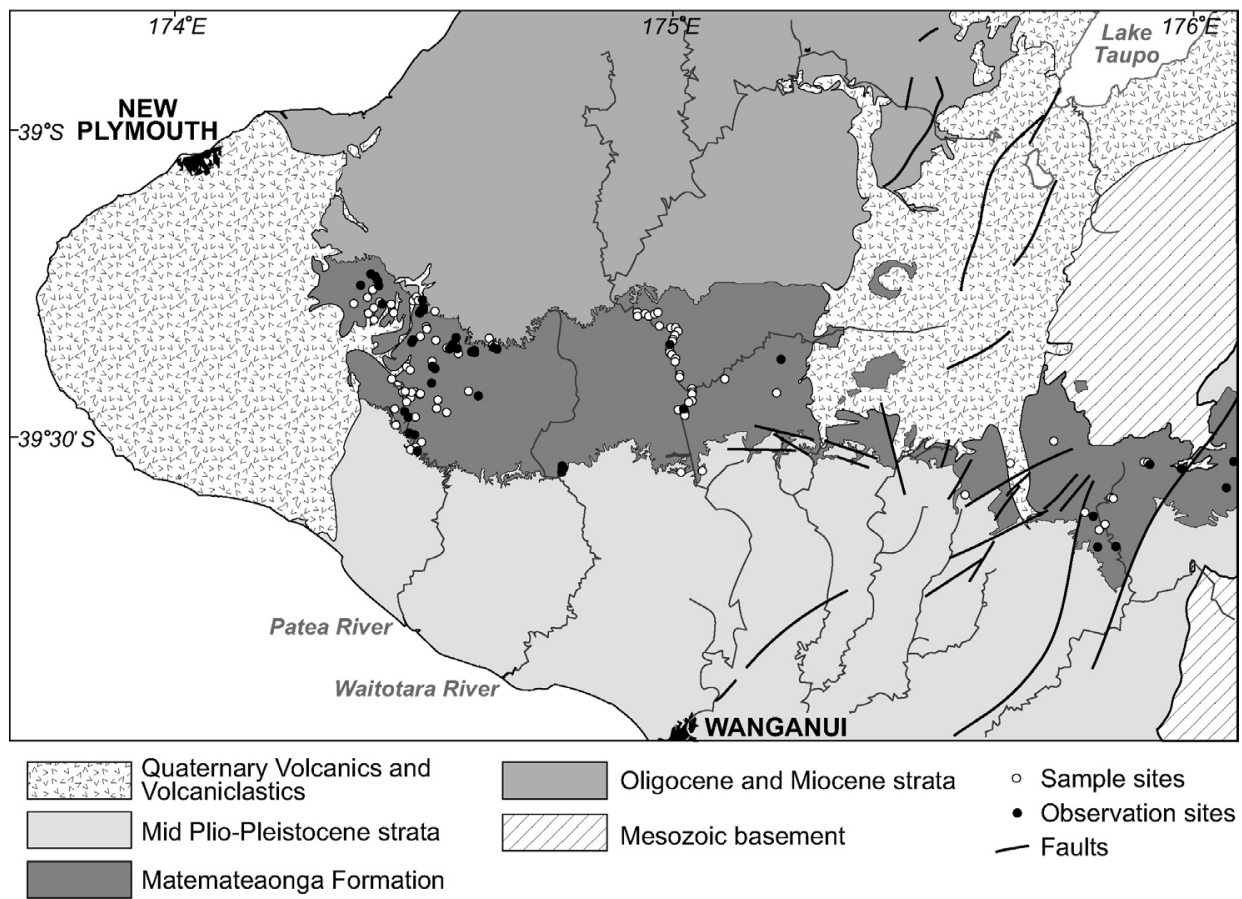

Fig. 1 Distribution of Matemateaonga Formation in Wanganui Basin and location of samples and field observations used in this investigation (adapted from Kamp et al. 2004).

units are characterised by laterally discontinuous bioclast and conglomerate filled channels and canyons within massive to laminated mudstone (King \& Thrasher 1996; Vonk et al. 2002). The concentrated and transported skeletal material observed in channels of the Kiore and Urenui Formations are inferred to have originated from the same inner shelf fauna that contributed to contemporary shelfal sediments of the Matemateaonga Formation. The upper contact of the formation is nearly isochronous, reflecting the marked and rapid flexural downwarping (pulldown) of Wanganui and southern Taranaki Basins during the lower Opoitian, at c. 4.7 Ma (Kamp et al. 2004). The Matemateaonga Formation is abruptly, but conformably, overlain by the Tangahoe Mudstone. This unit comprises a thick and often monotonous massive to poorly bedded succession of blue-grey, sandy mudstone that makes up the lower Taihape Group.

Within the outcrop belt, the Matemateaonga Formation ranges in thickness between 1000 and $2000 \mathrm{~m}$, although these estimates are aggregated over considerable distances as the beds dip at $3-4^{\circ}$ to the south or southwest. Internally the formation is characteristically cyclothemic, reflecting accumulation under conditions of oscillating sea level (Vonk et al. 2002; Kamp et al. 2002, 2004). A paleomagnetic and biostratigraphic chronostratigraphy suggests that oscillation in relative sea level occurs over intervals of c. $41000 \mathrm{yr}$, and hence falls within the temporal constraints of sixthorder cyclicity. Cyclothems or sequences are typically 40-80 $\mathrm{m}$ thick and have a repetitive internal architecture comprising, in ascending order, a shellbed (bioclastsupported bivalve-dominated facies) member (decimetre to metre thick, transgressive systems tract, TST), a siltstone member (highstand systems tract, HST), followed by a silty sandstone or sandstone member (regressive systems tract, RST). The sequence stratigraphic model developed for asymmetric sequences in the Rangitikei valley of late Pliocene age (e.g., Naish \& Kamp 1997a; Kamp \& McIntyre
1998) can be very easily applied to the sequences in the Matemateaonga Formation (Vonk et al. 2002; Kamp et al. 2004). In application of shellbed nomenclature we follow the schemes outlined in Kidwell (1991) and Naish \& Kamp (1997a).

\section{FIELD SAMPLING}

The collection of macrofaunal samples was undertaken throughout the outcrop extent of the Matemateaonga Formation in central to western North Island (Fig. 1). Efforts were made to sample a representative range of facies corresponding to inner to outer shelf paleoenvironments and from all systems tracts. A limited number of samples were collected from upper Tongaporutuan sequences, more from Kapitean sequences, with the majority of collections coming from lower Opoitian strata (Fig. 2). Sampling was most intensive in eastern Taranaki Peninsula hill country from Opoitian beds because of the availability of accessible outcrop, and these collections represent predominantly inner shelf paleoenvironments. Collections from the Wanganui River section of the basin sampled a range of inner shelf to outer shelf siliciclastic paleoenvironments, while those from the eastern margin of Wanganui Basin commonly represent innermost shelf paleoenvironments.

Assemblages from TSTs (typically lithified) are overrepresented in this study because the shellbeds they comprise are rich in macrofauna, well exposed, and obvious sampling targets. The siliciclastic sediment-dominated HSTs and RSTs (poorly lithified to lithified) are much less fossiliferous, variously exposed, and consequently under-represented in the quantitative analysis. This is partly overcome by reference to numerous field observations (Fig. 1) (Hendy 2003) and quantitative analysis of biofacies of HSTs and RSTs analysed in Manutahi-1 core. 


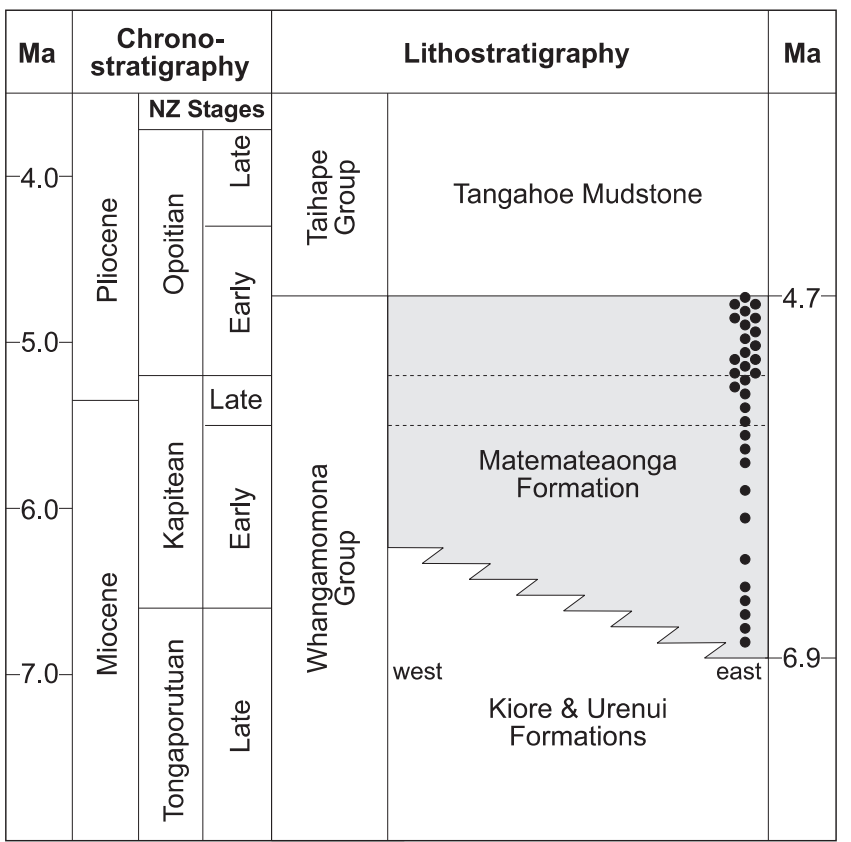

Fig. 2 Biostratigraphic subdivision of the Matemateaonga Formation and relative sampling intensity $(\bullet)$.

\section{DATA ANALYSIS}

Quantitative analyses were used to discriminate the number of biofacies occurring in the Matemateaonga Formation. These analyses were based on macrofossil bivalve, gastropod, scaphopod, brachiopod, and echinoderm identifications and abundance data obtained from bulk samples typically $3-5 \mathrm{~kg}$ in weight. Fragments of molluscs were only counted if they incorporated the apex or aperture in the case of gastropods and umbonal region or complete posterior and anterior margins of bivalves. The number of disarticulated specimens recorded was subsequently halved as bivalved invertebrates can produce double the number of countable skeletal elements compared with other common groups (i.e., gastropods) (Gilinsky \& Bennington 1994). Taphonomic attributes of assemblages were also noted during data collection to assess biostratinomic or diagenetic bias.

All statistical analyses were conducted at genus (or subgenus, if possible) level, following similar methods to those used by Patzkowsky \& Holland (1999) and Olszewski \& Patzkowsky (2001). Most genera encountered within the Matemateaonga Formation are represented by a single species, or by one dominant species. Samples comprising few specimens ( $<30$ individuals) and very rare taxa ( $<2$ occurrences) were excluded from the analyses, while lowdiversity samples were retained. With these considerations, the following analyses are based on 153 samples and 69 genera, representing over 20000 specimens (mean sample size $=135$ specimens).

Data were analysed using two principal techniques, cluster analysis (R-mode and Q-mode) and ordination (Detrended Correspondence Analysis) to distinguish biofacies and their faunal composition (Hendy 2003), although only the former is presented here. Cluster analysis is a commonly used method for the identification of paleoecological groups in multivariate datasets (Scott 1974; Dodd \& Stanton 1981; Springer \& Flessa 1996).

\begin{tabular}{|c|c|c|c|c|}
\hline \multirow{2}{*}{ Taxon } & \multicolumn{4}{|c|}{ Bathymetric range } \\
\hline & 0 & $20-30$ & $50-60$ & $100-120$ \\
\hline Zethalia zelandica * & & - & & i \\
\hline Ruditapes largillierti & & & & \\
\hline Stiracolpus spp. ${ }^{*}$ & & & & 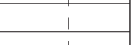 \\
\hline Tawera spissa * & & & 1 & 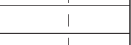 \\
\hline Dosinia greyi & । & & & i \\
\hline Zenatia acinaces & r & & & 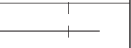 \\
\hline Maorimactra ordinaria * & 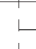 & & & 1 \\
\hline Oxyperas elongata * & 1 & & & 1 \\
\hline Ostrea chilensis & & & 1 & 1 \\
\hline Tucetona laticostata & & & 1 & T \\
\hline Modiolus areolatus & & & & 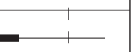 \\
\hline Zeacolpus vittatus & 1 & & & 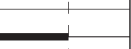 \\
\hline Neothyris lenticularis & 1 & & 1 & - \\
\hline Crepidula spp. & D & $\frac{1}{1}$ & 1 & 1 \\
\hline Pratulum pulchellum * & & I & T & -15 \\
\hline Notocallista multistriata * & & & & -160 \\
\hline
\end{tabular}

Fig. 3 Bathymetric range of key extant taxa. Note: * denotes extant taxa used as proxy for extinct form. Supporting data and explanations of the relationship between extant taxa and those investigated in the Matemateaonga Formation are presented in Appendix 1.

Examples of this type of analysis on New Zealand fossil assemblages are limited, but include Haywick \& Henderson (1991), Abbott \& Carter (1997), and Naish \& Kamp (1997b). Clustering was conducted using the unweighted pair group method with arithmetic averaging (UPMGA). R-mode cluster analysis used the modified Morisita's coefficient to generate a dendrogram that clusters commonly co-occurring species. Q-mode cluster analysis used the arithmetic averages of a Bray-Curtis distance matrix (weighted towards dominants) to produce a dendrogram classification of samples with similar faunal composition. Cluster analyses were performed using the PC Multi-Variate Statistical Package (MVSP; Kovach 1999).

Ecological data for dominant and characteristic extant taxa and closely related modern taxa are summarised in Appendix 1 and are presented in Fig. 3. This information is gathered from a variety of sources, most notably unpublished NIWA (National Institute of Water and Atmospheric Research, New Zealand) benthic sample data for the modern continental shelf off west coast North Island and Hawke's Bay, which have similar shelf morphologies and benthic environments to those of late Miocene to early Pliocene Wanganui Basin. This is supplemented by published data from shallow-water environments of northern New Zealand (e.g., Grace \& Hayward 1980; Hayward et al. 1986) and the northern South Island (e.g., Dell 1951a,b). The advantage of these faunal lists over other commonly used sources of published depth range data (e.g., Powell 1979) is that they allow estimation of relative abundance across bathymetric gradients (Gaussiantype distribution) as opposed to depth ranges based on museum specimens and anecdotal evidence. The reliability of transferring ecologic data from modern organisms to those 


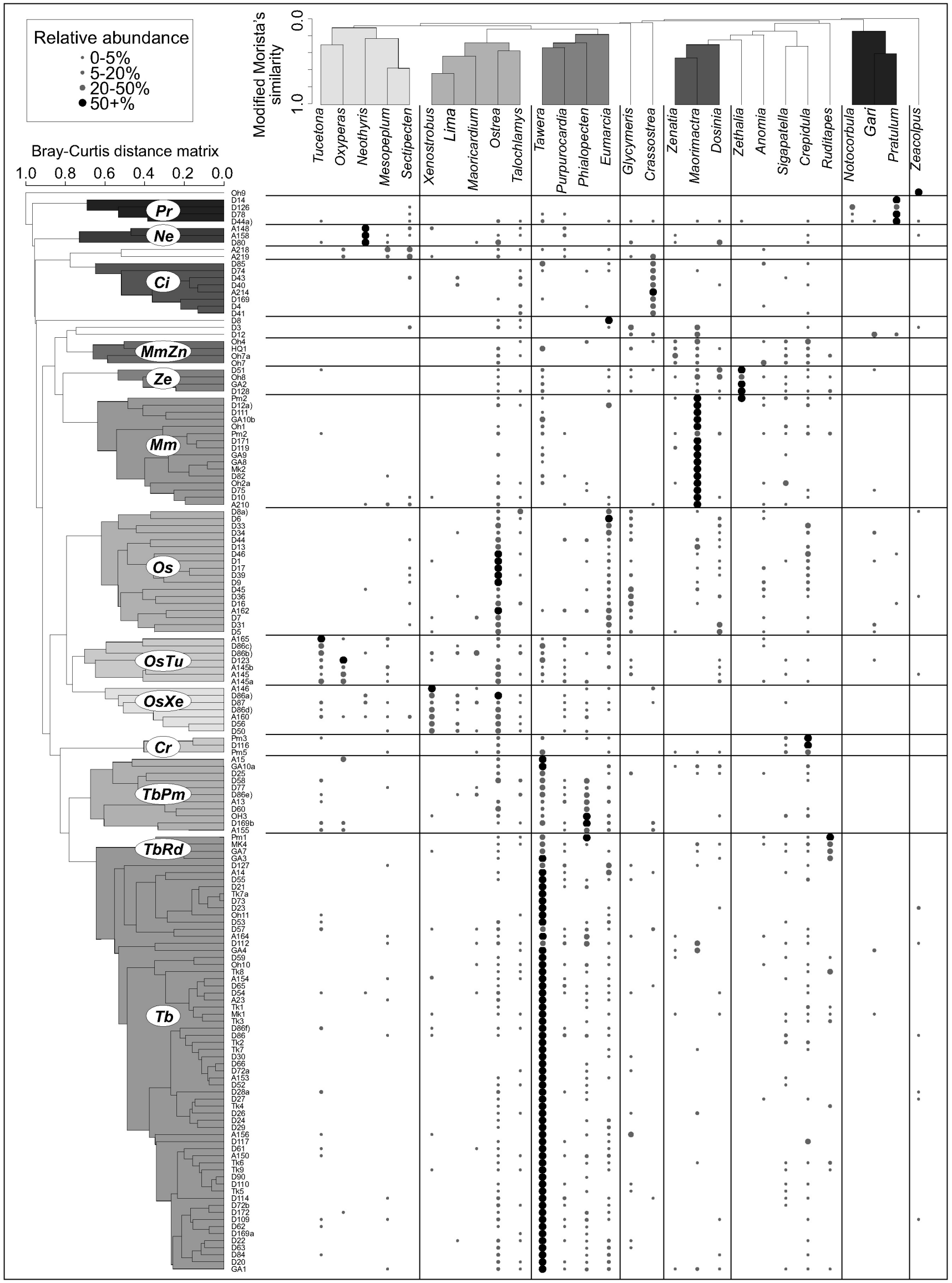

Fig. 4 Two-way cluster analysis of assemblages in the Matemateaonga Formation. Clusters are labelled by their biofacies codes (referred to in text and tables). 
in the fossil record depends on the supposition that extinct species had similar ecological requirements to closely related or morphologically similar extant forms (Beu et al. 1990). This is not necessarily completely true, as many groups of organisms have changed their ecologic preferences through time, or have become restricted to a portion of their former habit. Confidence in the ecologic tolerances assigned to biofacies described here is provided by: (1) the use of as many reliable taxa as possible, and (2) the use of extant taxa in biofacies as benchmarks for comparison. A more detailed discussion of the reliability of extant and extinct taxa as paleoenvironmental indicators is provided by Beu et al. (1990).

\section{RESULTS}

The two-way cluster analysis (Fig. 4) includes a Q-mode dendrogram (vertical axis), which relates bulk samples to one another based on their faunal content and an R-mode dendrogram (horizontal), which relates faunal components to one another based on their co-presence or co-absence in samples. The Q-mode analysis of 153 bulk samples from the Matemateaonga Formation produced 12 distinct groupings (clusters) of 3 samples or more. These provide the classification framework for identification and delineation of biofacies. A reduced dataset was used to construct the R-mode dendrogram for the two-way cluster analysis of Fig. 4, incorporating only those genera contributing $>1 \%$ each to the total abundance of Matemateaonga Formation samples. Eliminating the rare taxa (taxa that contribute $<1 \%$ each to the total abundance) filtered out the noise exhibited in dendrograms produced from full datasets.

Three major subsets, evident in the Q-mode dendrogram of Fig. 4, are characterised by the presence of Tawera, Ostrea, and Maorimactra, respectively. The Tawera-dominated subset comprises three discrete clusters characterised by: (1) Tawera-dominated samples (Tb); (2) the co-occurrence and even abundance of Tawera and Phialopecten (TbPm); and (3), the even abundance of Tawera and Ruditapes (TbRd). These biofacies are almost entirely composed of samples from TST shellbeds. A further cluster $(\mathrm{Cr})$ branches off the Tawera-dominated subset and is characterised by the abundant calyptraeid Crepidula, with rare or uncommon Tawera.

The second major subset in the Q-mode dendrogram was characterised by the presence of common and abundant Ostrea in bulk samples. This subset includes three discrete clusters characterised by: (1) the co-dominance of Ostrea and Oxyperas (Os); (2) co-dominant Tucetona and Ostrea (OsTu); and (3), even abundance of Xenostrobus and Ostrea (OsXe). These biofacies were common in sediment-starved facies of TSTs, and surfaces of maximum starvation in the early HST.

A third subset includes the bulk of the remaining samples and is characterised by the presence of Maorimactra. Most samples within this subset are collected from HSTs and RSTs, although some TST shellbeds that accumulated in sheltered offshore paleoenvironments may be included here. Clusters within this subset include: a large cluster produced by samples in which Maorimactra is numerically dominant (Mm); a second cluster comprising samples dominated by Zethalia (ZeFe); and a cluster produced by mixed assemblages, characterised by the presence of Zenatia, Maorimactra, Crepidula, and Sigapatella (MmZn).
Three other small clusters in Fig. 4 are clearly segregated from each other and the three major subsets described above. These include samples characterised by: (1) the presence of common Crassostrea, with uncommon Talochlamys (Ci); (2) abundant Neothyris, uncommon pectinids, and Ostrea (Ne); and (3), a final cluster (Pr), characterised by abundant Pratulum and uncommon Notocorbula and Sectipecten.

\section{BIOFACIES OF THE MATEMATEAONGA FORMATION}

Altogether 15 benthic associations and sub-associations can be discriminated within Matemateaonga Formation fossil assemblages on the basis of quantitative techniques and field observations. These are listed in Table 1, together with general sedimentologic and taphonomic characteristics. Table 2 summarises the dominant and characteristic taxa of each of these biofacies, and Fig. 5 graphically presents the mean relative abundance of the most common taxa in each biofacies. The purpose of the following section is to give an environmental interpretation of these associations and subassociations, summarised in Fig. 5.

Sedimentary and taphonomic evidence, which support inferences made on the general environmental tolerances of each association together with autoecologic data, are summarised in Table 1. Relating these associations to their original paleocommunity composition is straightforward for assemblages sampled from siliciclastic-dominated facies of HSTs and RSTs in the Matemateaonga Formation. These show evidence of little transportation or reworking, and can be considered to be "census assemblages" or have undergone "within-habitat time averaging" and hence have high ecologic fidelity (Kidwell \& Bosence 1991). Most samples used in the cluster analysis were, however, from condensed carbonatedominated facies of TSTs and are variably mixed, transported ("within-habitat time averaged" and "environmentally condensed") assemblages (Kidwell \& Bosence 1991). Associations that result from analyses of such samples still retain characteristics similar to modern benthic communities, allowing some confidence in their ecologic fidelity.

\section{Biofacies of sediment-starved (TST) paleoenvironments} Crassostrea Association ( $\mathrm{Ci}$ )

This association is characterised by the large thick oyster Crassostrea ingens, which may be preserved as (1) a reworked coquina of disarticulated valves, or (2) thick (1-2 m) biostromes. These biostromes are similar to those described by Fleming (1953), Christie (1973), and McIntyre (2001) from the late Pliocene (Mangapanian) Wilkies Shellbed. Occurrence of Crassostrea on the basement onlap surface (late Miocene, lower Kapitean) in Manutahi-1 core demonstrates that the species may also have encrusted rocky surfaces.

An important misconception regarding the paleoecological distribution of faunas dominated by $C$. ingens has been that they occupied reduced salinity environments, similar to modern Crassostrea (Beu et al. 1990). This is based on observations of biostrome formation in the extant North American C. virginica and Asian C. gigas, which flourish in estuarine environments rather than being restricted to fully marine settings (Kennedy et al. 1996). Evidence that the $C$. ingens association occupied fully marine environments includes: (1) its presence in thick transgressive biostromic shellbeds (e.g., McIntyre 2001; Hendy 2003) in association 


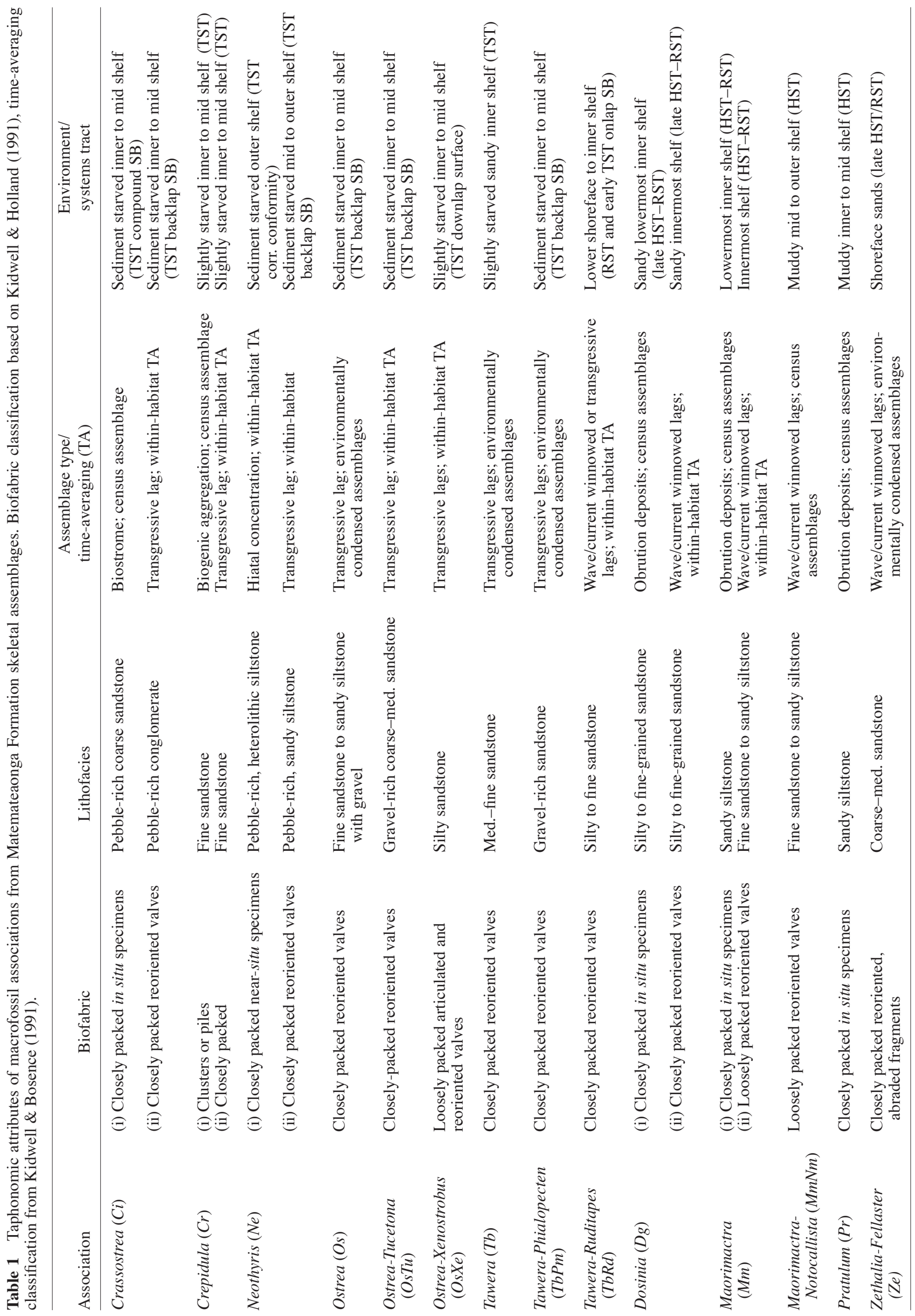


with fully marine taxa; and (2) stable isotope and aminoacid profiles of $C$. ingens and similar North American Oligocene-Pliocene Crassostrea reveal extremely high growth rates, suggesting a more subtidal habitat, where food was continuously available (Mitchell et al. 1995; Kirby et al. 1998; Kirby 2000). The environmental tolerances, for instance bathymetric distribution, of $C$. ingens remain poorly understood, however, along with the causes for sudden proliferation during the development of sequences at particular times. A shallow, probably inner to upper mid-shelf depth range is inferred for this association (Fig. 6) based on the presence of co-occurring shallow-water taxa.
Crepidula Association ( $\mathrm{Cr}$ )

The fauna of this association has low diversity (Table 2), with most beds containing either: (1) tightly packed specimens of the oyster Ostrea chilensis and Crepidula radiata; or (2) clustered reproductive aggregations of $C$. radiata only (e.g., Beu et al. 1990; Grant-Mackie 1990). The common association with Ostrea chilensis in the Matemateaonga Formation suggests that oysters were a host for Crepidula, which commonly occupies hard substrates such as stones and shells (Beu et al. 1990). Its dominance in some samples, however, indicates that the extinct $C$. radiata was also an opportunist species, invading and out-competing other taxa when environmental

Table 2 Macrofaunal associations and important constituent species identified from the Matemateaonga Formation.

\begin{tabular}{|c|c|c|c|}
\hline Association & Association & Dominant taxa & Secondary taxa \\
\hline Crassostrea $(\mathrm{Ci})$ & Crassostrea & $\begin{array}{l}\text { Crassostrea ingens, } \\
\text { Austromegabalanus miodecorus, } \\
\text { Fosterella tuberculatus, } \\
\text { Tasmanobalanus acutus acutus }\end{array}$ & $\begin{array}{l}\text { Mesopeplum hilli, Sectipecten wollastoni, } \\
\text { Talochlamys gemmulata, Ostrea chilensis }\end{array}$ \\
\hline Crepidula $(\mathrm{Cr})$ & Crepidula & Crepidula radiata, Ostrea chilensis & Tawera bartrumi, Sigapatella novaezelandiae \\
\hline Neothyris $(\mathrm{Ne})$ & Neothyris & Neothyris sp. & $\begin{array}{l}\text { Xenostrobus altijugatus, Sectipecten wollastoni, } \\
\text { Ostrea chilensis, Purpurocardia purpurata }\end{array}$ \\
\hline Ostrea $(O s)$ & Ostrea & $\begin{array}{l}\text { Ostrea chilensis, Oxyperas } \\
\text { komakoensis, Tawera bartrumi }\end{array}$ & $\begin{array}{l}\text { Glycymeris mahiana, Glycymerita spp., } \\
\text { Talochlamys gemmulata, Anomia trigonopsis, } \\
\text { Eumarcia benhami, Crepidula radiata }\end{array}$ \\
\hline $\begin{array}{l}\text { Ostrea-Tucetona } \\
(\text { OsTu })\end{array}$ & $\begin{array}{l}\text { Ostrea- } \\
\text { Tucetona }\end{array}$ & $\begin{array}{l}\text { Tucetona laticostata, Ostrea chilensis, } \\
\text { Oxyperas komakoensis }\end{array}$ & $\begin{array}{l}\text { Glycymeris mahiana, Lima waipipiensis, } \\
\text { Maoricardium spatiosum, Purpurocardia } \\
\text { purpurata, Eumarcia benhami, Tawera bartrumi }\end{array}$ \\
\hline $\begin{array}{l}\text { Ostrea- } \\
\text { Xenostrobus } \\
(\text { OsXe })\end{array}$ & $\begin{array}{l}\text { Ostrea- } \\
\text { Xenostrobus }\end{array}$ & $\begin{array}{l}\text { Xenostrobus altijugatus, Ostrea } \\
\text { chilensis }\end{array}$ & $\begin{array}{l}\text { Tucetona laticostata, Talochlamys gemmulata, } \\
\text { Lima waipipiensis, Tawera bartrumi, } \\
\text { Neothyris sp. }\end{array}$ \\
\hline Tawera $(T b)$ & Tawera & $\begin{array}{l}\text { Tawera bartrumi, Ostrea chilensis, } \\
\text { Eumarcia benhami, Oxyperas } \\
\text { komakoensis }\end{array}$ & $\begin{array}{l}\text { Tucetona laticostata, Phialopecten marwicki, } \\
\text { Maorimactra chrydaea, Purpurocardia } \\
\text { purpurata, Crepidula radiata }\end{array}$ \\
\hline $\begin{array}{l}\text { Tawera- } \\
\text { Phialopecten } \\
(\text { TbPm })\end{array}$ & $\begin{array}{l}\text { Tawera- } \\
\text { Phialopecten }\end{array}$ & $\begin{array}{l}\text { Phialopecten marwicki, Ostrea } \\
\text { chilensis, Tawera bartrumi }\end{array}$ & $\begin{array}{l}\text { Purpurocardia purpurata, Eumarcia benhami, } \\
\text { Struthiolaria spp., Polinices waipipiensis, } \\
\text { Crepidula radiata, Sigapatella novaezelandiae }\end{array}$ \\
\hline $\begin{array}{l}\text { Tawera- } \\
\text { Ruditapes } \\
(\text { TbRd })\end{array}$ & $\begin{array}{l}\text { Tawera- } \\
\text { Ruditapes }\end{array}$ & $\begin{array}{l}\text { Ruditapes largillierti, Tawera } \\
\text { bartrumi }\end{array}$ & $\begin{array}{l}\text { Ostrea chilensis, Maorimactra chrydaea, } \\
\text { Dosina zelanica, Crepidula radiata }\end{array}$ \\
\hline Dosinia $(D g)$ & Dosinia & $\begin{array}{l}\text { Dosinia greyi, Zeacolpus. spp., } \\
\text { Stiracolpus spp. }\end{array}$ & Maorimactra chrydaea, Tawera bartrumi \\
\hline $\begin{array}{l}\text { Maorimactra } \\
(\mathrm{Mm})\end{array}$ & Maorimactra & Maorimactra chrydaea & $\begin{array}{l}\text { Zenatia acinaces, Tellinota edgari, Dosinia } \\
\text { greyi, Notocallista makoensis }\end{array}$ \\
\hline $\begin{array}{l}\text { Maorimactra- } \\
\text { Notocallista } \\
(\mathrm{MmNm})\end{array}$ & $\begin{array}{l}\text { Maorimactra- } \\
\text { Notocallista }\end{array}$ & $\begin{array}{l}\text { Notocallista makoensis, } \\
\text { Maorimactra chrydaea }\end{array}$ & \\
\hline Pratulum $(P r)$ & Pratulum & Pratulum finlayi & $\begin{array}{l}\text { Cucullaea hamptoni, Tawera bartrumi, } \\
\text { Notocorbula humerosa }\end{array}$ \\
\hline $\begin{array}{l}\text { Zethalia- } \\
\text { Fellaster }(Z e)\end{array}$ & $\begin{array}{l}\text { Zethalia- } \\
\text { Fellaster }\end{array}$ & Zethalia russelli, Fellaster zelandiae & $\begin{array}{l}\text { Perna canaliculus, Paphies spp., Dosinia } \\
\text { kaawaensis, Ruditapes largillierti, Tawera } \\
\text { bartrumi, Myadora waitotarana, Amalda } \\
\text { depressa, Pervicacia tristis }\end{array}$ \\
\hline
\end{tabular}




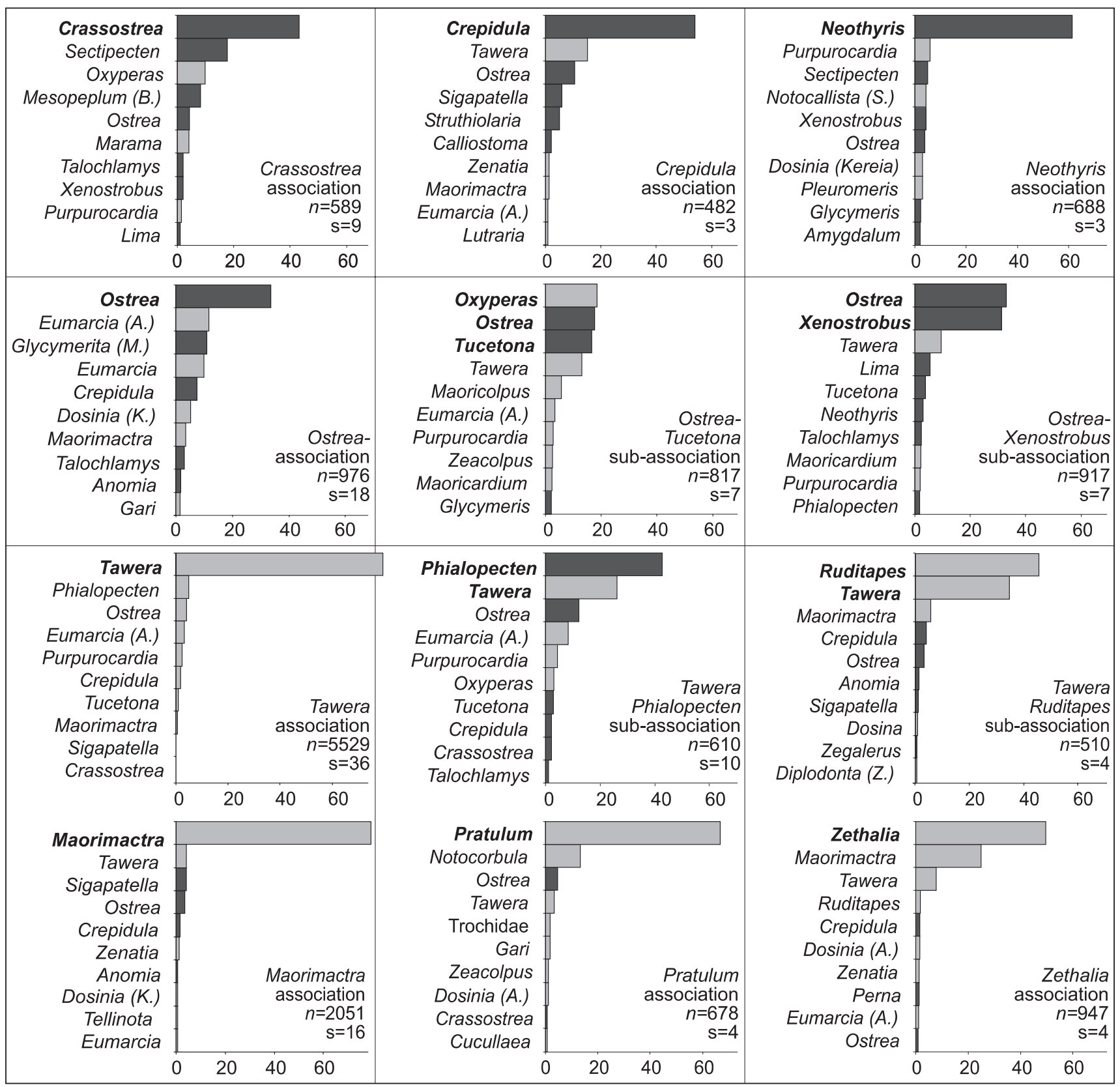

Fig. 5 Histograms of mean relative abundance of the most common taxa in biofacies of the Matemateaonga Formation. Infauna (light grey), epifauna and semi-infauna (dark grey), $n=$ number of individuals, $\mathrm{s}=$ number of samples, characteristic taxa (bold).

conditions became favourable (e.g., Miller \& Dubar 1988). Such behaviour is apparent in the European $C$. fornicata, which has been documented to rapidly invade new habitats (e.g., da Montaudouin et al. 1999; Chauvand et al. 2000) and through its piling and agglomeration of biogenic mud to modify sediment texture and consistency to its own advantage (Ehrhold et al. 1998). The association is predicted to have occurred in innermost shelf to outer shelf depths (Fig. 6), where the substrate was stable enough to support the epifaunal $O$. chilensis, which is most commonly encountered in inner to mid-shelf depths $(0-80 \mathrm{~m})$ (Fig. 3), but fine enough to preclude other epifaunal taxa.

\section{Neothyris association ( $\mathrm{Ne})$}

This association is composed of both infaunal and epifaunal taxa, being dominated by an undetermined species of the brachiopod genus Neothyris. It is uncommonly encountered and restricted in distribution to the western (offshore) parts of the basin and upper Kapitean strata. It is peculiar that brachiopods in general are scarce in the Matemateaonga Formation. This contrasts strongly with younger units of the Wanganui and East Coast Basins, which are comparatively rich in brachiopod faunas (e.g., Fleming 1953; Neef 1997). Modern Neothyris occupy a depth range of c. 20-400 m (Neall 1970), and analyses of benthic sample data suggest 
Fig. 6 Inferred cross-shelf distribution and relative abundance of biofacies within: (A) sedimentstarved; and (B) high-sedimentation shelf environments.

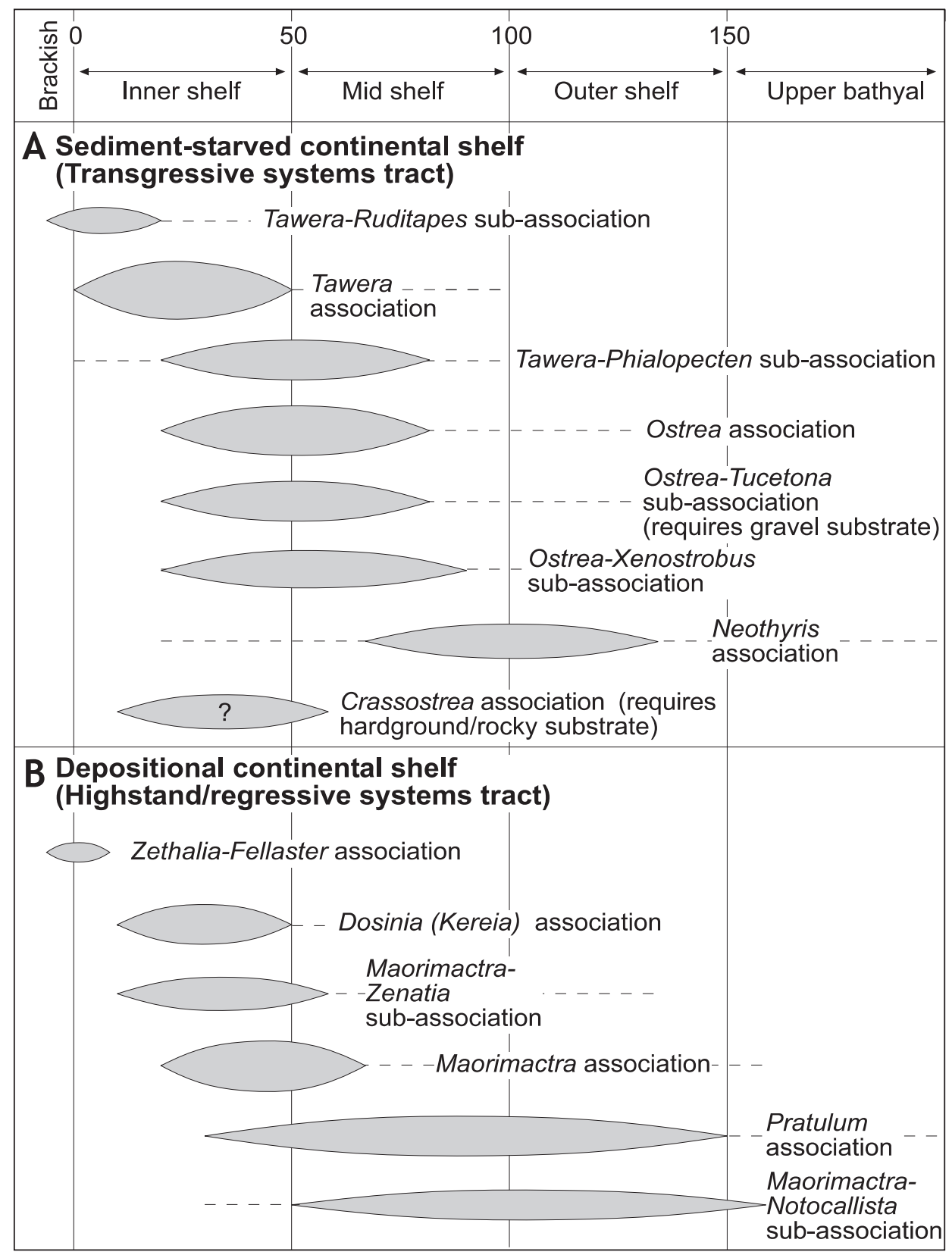

that the species is most common over depths of 70-130 m (Fig. 3), although environmental conditions such as very low sedimentation rates and/or high turbulence may account for the species' distribution (Neall 1970). The Neothyris association in the Matemateaonga Formation is therefore inferred to have occupied a paleobathymetric range of midshelf to outer shelf depths (Fig. 6).

\section{Ostrea Association (Os)}

The characteristic members of this association include the oyster Ostrea chilensis, the infaunal bivalves Oxyperas (Pseudoxyperas) komakoensis and Tawera bartrumi, and several semi-infaunal glycymerid taxa (Table 2). The Ostrea association comprises many taxa common to modern, offshore inner to mid-shelf environments. Ostrea chilensis, itself, has been regarded as a good indicator of inner-shelf environments (Beu et al. 1990), although analysis of benthic sample data suggests that $O$. chilensis has a wider bathymetric distribution, being most common in depths of 0-80 m (Fig. 3). Other important contributing taxa such as $O$. (Pseudoxyperas) komakoensis and T. bartrumi are inferred to have similar bathymetric ranges. The Ostrea association is therefore inferred to occupy lower inner to mid-shelf sediment-starved environments (Fig. 6).

\section{Ostrea-Tucetona sub-association $(\mathrm{OsTu})$}

This sub-association is composed of a mixture of infaunal, semi-infaunal, and epifaunal taxa, and is distinguished from the Ostrea association by the dominance of Tucetona laticostata, while the large infaunal bivalve Oxyperas, and the oyster Ostrea are common. On the modern New Zealand shelf, the extant $T$. laticostata is an abundant member of coarse substrate communities, particularly in the presence of high current activities, for instance current-swept channels 
(Powell 1937; Fleming 1952; Morton \& Miller 1968). Tucetona laticostata is recorded from a wide bathymetric range across the inner to outer shelf (Fig. 3), but is most common in shallower depths $(20-80 \mathrm{~m})$ along with other characteristic taxa in this association. The sub-association is inferred to have lived in lower inner shelf to mid-shelf environments (Fig. 6), where coarse sediment (cobble or pebble size) was available.

\section{Ostrea-Xenostrobus sub-association $(\mathrm{OsXe})$}

This sub-association is characterised by co-dominance of the oyster Ostrea chilensis and the epibyssate mussel Xenostrobus altijugatus. The Ostrea-Xenostrobus sub-association represents a paleocommunity of predominantly epifaunal organisms living on or partially buried (semi-infaunal) in a firm gravel-rich muddy substrate during maximum flooding periods (late TST/early HST). Although $X$. altijugatus is not extant, similar modern benthic communities comprising $O$. chilensis and morphologically similar mytilid bivalves (e.g., Modiolus areolatus) have been noted in offshore settings (Dell 1951a; Fleming 1952). The sub-association probably occurred in lower inner shelf to mid-shelf depths (Fig. 6), probably at the lower extent of the depth range of $O$. chilensis $(20-80 \mathrm{~m})$. The loose packing of assemblages containing this sub-association in muddy sediments suggests that sedimentation rates were probably higher during their accumulation as sea level reached its maximum flooding level and sediment starvation came to an end.

\section{Tawera association $(\mathrm{Tb})$}

This association is the most ubiquitous fauna encountered in transgressive facies of the Matemateaonga Formation, and is typically diverse (Table 2), although dominated by the shallow burrowing bivalve Tawera bartrumi. The Tawera association is recorded from upper Kapitean and Opoitian strata, but similar shallow-water Tongaporutuan-age facies lack Tawera bartrumi. Modern Tawera-dominated communities typically occur in clean sandy substrates extending offshore from the shoreface environment (McKnight 1969a; Grace \& Whitten 1974; Grace \& Hayward 1980; Hayward et al. 1981) (Fig. 3). In coarse sediment these communities have been observed to grade into assemblages containing semi-infauna such as Tucetona (Grace \& Whitten 1974). Hayward et al. (1981) reported the occurrence of very dense beds of the modern T. spissa in northern New Zealand, reaching densities of up to 25000 per $^{2}$. It is inferred that Tawera-dominated shellbeds in the Matemateaonga Formation accumulated from similar dense communities in an inner shelf $(0-50 \mathrm{~m})$ setting above storm-wave base (Fig. 6), through successive reworking, burial, recolonisation, exhumation, and reworking events.

\section{Tawera-Phialopecten sub-association (TbPm)}

The sub-association is dominated by individuals of epifaunal taxa, in particular the scallop Phialopecten marwicki and the oyster Ostrea chilensis. The Tawera-Phialopecten sub-association is characterised by a high proportion of individuals of epifaunal taxa, typical of faunas occupying firmgrounds or environments severely starved of terrigenous sediment. Encrustation and bioerosion is commonly observed in many assemblages containing the Tawera-Phialopecten sub-association, and is further evidence supporting sediment deprivation and the processes of time-averaging that result from these conditions (Kidwell \& Jablonski 1983; Kidwell \& Bosence 1991). The sub-association may be observed from either: (1) thin (decimeter thickness) horizons within basal TST deposits (short-duration omission events); or more commonly (2), the upper portions of backlap shellbeds (prolonged periods of maximum sediment starvation). A lower inner shelf to mid-shelf bathymetric range (20-80 m) is inferred for this association (Fig. 6) based on the preferred depth range of $O$. chilensis and Tawera bartrumi (Fig. 3), and the inferred tolerances of P. marwicki (Beu et al. 1990).

\section{Tawera-Ruditapes sub-association (TbRd)}

The sub-association is co-dominated by Tawera bartrumi and Ruditapes largillierti, which often share similar abundance. Ruditapes largillierti is abundant today in shallow water (0-20 m) (Fig. 3), occupying silty and sandy substrates of large embayments (Grace 1966; Powell 1979; Brook \& Grace 1981; Beu et al. 1990). Faunas of this sub-association, which are often recorded in the lowermost (inferred to be shallowest) parts of TST shellbeds, or in the uppermost parts of the RST, are likely to have accumulated in protected embayments in rather shallow water (Fig. 6). These paleoenvironmental conditions are predicted to have been more common along the eastern margin of Wanganui Basin, reflecting the association's limited distribution. It is inferred that the sub-association graded into the T. bartrumi association farther offshore.

\section{Biofacies of high sedimentation (HST/RST) paleoenvironments}

\section{Dosinia (Kereia) association $(D g)$}

The Dosinia association, uncommonly found in silty and fine sandstone, is characterised by the dominance of Dosinia (Kereia) greyi, which is often associated with turritellid gastropods of the genera Zeacolpus and Stiracolpus, and rare Maorimactra chrydaea and Tawera bartrumi. Dosinia (Kereia) greyi is an extant taxon, occurring preferentially in sheltered inner shelf settings (Fig. 3). Taphonomic evidence (e.g., regular preservation as rapidly buried or somewhat winnowed assemblages) suggests this association also occurred below fair-weather wave-base, but above storm wave-base. Its occurrence as relatively continuous densely packed beds of in situ to reworked articulated individuals suggests that it was a gregarious faunal association, rapidly proliferating in local environments when conditions were favourable. The Dosinia association, therefore, appears to have been an important biofacies on the lower inner shelf (10-50 m) where level bottom substrates comprised relatively coarse, stable sediments (Fig. 6).

\section{Maorimactra association ( $\mathrm{Mm}$ )}

Assemblages representing this association are the most commonly encountered faunas in silty sandstone and fine sandstone of the HST and RST of Matemateaonga Formation sequences. The dominant species of the association is Maorimactra chrydaea, which is uncommonly associated with Zenatia acinaces, Tellinota edgari, Dosinia (Kereia) greyi, Notocallista (Striacallista) makoensis, and Tawera bartrumi. The closely related extant $M$. ordinaria occupies a broad bathymetric range $(10-170 \mathrm{~m})$, although it is most common shallower than $80 \mathrm{~m}$ (Fig. 3). Similar modern communities, dominated by $M$. ordinaria are recorded from shallower depths of 20-60 m (McKnight 1969b, 1974). Thus, this association is inferred to have occupied 
an offshore paleoenvironment, in inner to mid-shelf depths (c. 20-70 m) (Fig. 6), and potentially graded into more nearshore Maorimactra-Zenatia (MmZn) and Dosinia associations, and in an offshore direction the MaorimactraNotocallista association.

\section{Maorimactra-Notocallista sub-association ( $\mathrm{MmNm}$ )}

The characteristic species of this sub-association is the small infaunal bivalve Notocallista (Striacallista) makoensis, which may be associated with common Maorimactra chrydaea in fine sandstone and sandy siltstone. The extant $N$. (Striacallista) multistriata is most abundant in mid to outer shelf depths (50-160 m) and M. ordinaria, although common in inner to mid-shelf settings, is found across a broad bathymetric range $(0-160 \mathrm{~m})$ (Fig. 3). Modern benthic communities dominated by Notocallista have been described from depths $>40 \mathrm{~m}$ (Hayward et al. 1984). On account of the dominance of $N$. (Striacallista) makoensis and the absence of taxa typically restricted to inner shelf settings, the association probably occupied a mid-shelf to outer shelf benthic environment (Fig. 6). The Maorimactra-Notocallista sub-association is inferred to be a gradational end member of the Maorimactra association, probably occurring in deeper settings.

\section{Pratulum finlayi association (Pf)}

Assemblages dominated by Pratulum finlayi are generally low diversity, containing closely packed articulated specimens of the cardiid bivalve, often preserved in situ within sandy siltstone. The closely related modern cardiid $P$. pulchellum has an extremely broad bathymetric range, recorded from 17400 m by Luckens (1972). The majority of these occurrences, however, were in depths <200 m (Fig. 3), and associations dominated by $P$. pulchellum known in modern settings to occur in depths <150 m (Dell 1951a,b; Estcourt 1967; Grace \& Hayward 1980; Hayward et al. 1984). It is possible that the extinct $P$. finlayi had a similar depth range, although modern $P$. pulchellum communities are of much higher diversity than those containing $P$. finlayi, and generally lack inner-shelf taxa. Pratulum finlayi dominated assemblages in Matemateaonga Formation cyclothems are therefore inferred to have accumulated in muddy substrates of lower inner shelf to mid-shelf depth (Fig. 6), and certainly no deeper than the outer shelf given their close stratigraphic proximity to innershelf facies.

\section{Zethalia-Fellaster association (Ze)}

The Zethalia-Fellaster association is commonly associated with assemblages of high species diversity (Table 2), within medium-coarse and often cross-bedded sandstone. Assemblages are often mixed from a variety of very shallow water habitats and therefore serve as key indicators of nearshore-shoreface high-sedimentation environments. The clypeasteroid Fellaster zelandiae is commonly found in waters of <20 m depth (McKnight 1969a; Hayward et al. 1994), and the Zethalia lineage is also inferred to have been restricted to nearshore environments; the Recent Zethalia zelandica commonly occupies depths of 3-5 m (Beu et al. 1990) (Fig. 3). Other constituent taxa, including Paphies, Myadora, and Pervicacia are also typical members of nearshore sandy environments (Grace \& Whitten 1974; Grace \& Hayward 1980; Hayward et al. 1981). A depth range of $0-5 \mathrm{~m}$ is suggested for this association (Fig. 6).

\section{DISCUSSION}

\section{Paleoenvironmental distribution of biofacies}

The paleoenvironmental conditions that led to development of Matemateaonga Formation sequences can be established through analysis of the faunal content of fossil assemblages, their taphonomic characteristics, and the nature of associated lithologies. The ecologic characteristics of macrofaunal associations identified in the Matemateaonga Formation have been established from the known or inferred environmental tolerances of taxa in these associations and the environmental distribution of closely related modern benthic communities. Figure 6 summarises the inferred paleoenvironmental distribution of these associations, in particular their paleobathymetric ranges. The influence of three important environmental variables on the distribution of biofacies is discussed below. This provides data on the magnitude of paleoenvironmental change associated with sequence development in the late Miocene to early Pliocene strata of Wanganui Basin.

\section{(1) Substrate}

A range of lithofacies were sampled from the Matemateaonga Formation, representing inner to outer shelf environments. Soft substrate biofacies, such as the Maorimactra association and Maorimactra-Zenatia and Maorimactra-Notocallista sub-associations, occur in silty sediments of the inner to middle paleoshelf and are dominated by individuals of infaunal suspension-feeding bivalve taxa. In more offshore paleodepositional settings, the Pratulum association occurs in gregarious clumps within soft, "soupy" muddy substrates (e.g., Beu et al. 1990). The Dosinia association occupied sandier substrates, in shallower depths, than the Maorimactra association in higher energy innermost shelf environments. The Zethalia-Fellaster association would have been restricted to moderately coarse sandy substrates in very nearshore (i.e., HCS facies), high-energy settings (Morton \& Miller 1968).

Hardground and firmground substrates were occupied by the Ostrea and Crassostrea associations, which are dominated by individuals of cemented or byssally attached epifaunal suspension feeders, such as oysters, pectinids, and mytilids. Within thick successions of siltstone, episodically produced firmgrounds may be indicated by the Ostrea or Neothyris associations. Intermediate substrates, between firmgrounds and cohesive soft-bottoms, formed during intervals of sediment starvation and were often occupied by the Ostrea association, its sub-associations, and the Tawera-Phialopecten sub-association. A high proportion of taxa from these associations exhibit semi-infaunal and epifaunal life-habits, suggesting periods of stable conditions at the sediment/water interface. Coarser (medium to fine) sand, deposited during transgressive phases of sea-level change, appears to have been occupied by members of the Tawera association and Tawera-Ruditapes sub-association, which have increased representation by infaunal bivalves.

\section{(2) Wave/current activity}

Facies that accumulated in conditions of turbulent bottom water may also be characterised by associations dominated by individuals of epifaunal taxa, for instance the Ostrea association and sub-associations and the Tawera-Phialopecten sub-association. Epifaunal and semi-infaunal taxa, such as Ostrea chilensis, Phialopecten marwicki, and Tucetona 
laticostata are not inhibited by substrate scouring and flourished in conditions of sediment bypassing. Quiet offshore soft-bottom settings will be characterised by members of the Pratulum and Maorimactra associations and sub-associations. Higher energy nearshore and innermost shelf environments are characterised by taxa that can cope with intermittently shifting substrates, such as those from the Dosinia (Kereia), Maorimactra-Zenatia, and Zethalia-Fellaster associations. Low-energy firmground settings would have favoured sessile epifaunal taxa, such as members of the Neothyris association and Ostrea-Xenostrobus sub-association.

\section{(3) Salinity}

Most faunal associations identified from the Matemateaonga Formation are inferred to have lived in fully marine conditions. The rarity of characteristic estuarine and brackish taxa such as Austrovenus, Zeacumantus, and Amphibola suggests that faunas occupying greatly reduced salinities were either not sampled or are not well represented in the Matemateaonga Formation. The Tawera-Ruditapes association, however, may have occupied slightly reduced salinity environments given the presence of Ruditapes largillierti, which inhabits similar habitats today (Morton \& Miller 1968).

\section{Sequence stratigraphy and community replacement}

Paleoecology has a close relationship with sequence stratigraphy. Associations of fossil taxa may provide important indicators of successively changing environmental conditions, including depth, substrate consistency, sedimentation rate, turbidity, and sediment oxygenation, which are critical in recognising and interpreting systems tracts within sequences (Holland 1995; Brett 1998). Abrupt changes in faunal composition also provide some of the best guides in identifying key surfaces, such as sequence boundaries and maximum flooding surfaces, and inferring sedimentary dynamics within sequences. In another sense, the sequence stratigraphic model and the paleoenvironmental interpretations associated with it provide a predictive framework with which to examine biotic changes and understand their causes (Rollins et al. 1979; Brett 1998). One such biotic process associated with varying paleoenvironmental conditions occurring during sequence development is community replacement, a pattern of long-term faunal transition observed in sedimentary successions.

Community replacement occurs over time frames of tens to hundreds of thousands of years. Replacement in offshore settings appears to involve lateral shifts of broad shoreline-parallel biofacies belts or patches (faunal tracking of habitats), although this is sometimes a simplistic view (see Brett 1998 for a discussion of alternative scenarios). Community analysis of the continental shelf offshore of the western North Island, New Zealand (McKnight 1969, 1974; Hendy unpubl. data) reveals the distribution of faunal associations not only as belts (aligned parallel to shoreline), but also regionally restricted patches. These patterns closely match the distribution of surficial sediment grades, which relate to decreasing environmental energy in an offshore direction, localised sources of fluvial sediment input, and areas of relict carbonate sediment. The inferred distribution of Matemateaonga Formation biofacies on both sedimentstarved (TST) and depositional shelves (HST and RST) is presented in Fig. 7. These biofacies are predicted to have migrated laterally in response to shoreline transgression or regression and shelf progradation. In a sedimentary succession, these cycles of tracking may be symmetrical or asymmetrical depending on the rate of sedimentary input, deletion of portions of sequences (i.e., unconformable sequence boundaries), or the condensation of facies (Rollins et al. 1979; Holland 1995; Naish \& Kamp 1997a; Brett 1998). Furthermore, paleoecologic data may be missing from portions of sedimentary sequences through either: (1) erosion of underlying strata (commonly late RST/HST sediments) during marine transgression and erosion; or (2) nonpreservation of benthic communities through taphonomic processes (poor concentration, reworking, dissolution). A recurring pattern of biofacies distribution comes about because biofacies have discrete paleoenvironmental preferences that are only available at a particular site during specific portions of sea-level change and shelf paleogeography, conditions that may be reproduced in successive sequences. These faunal associations will continue to exist in other basins during subsequent phases of sea-level oscillation where appropriate conditions prevail. The modern New Zealand shelf provides an example of a setting where analogous benthic communities typical of both sediment-starved (TST) and high sedimentation (HST/RST) environments occur contemporaneously in regions where the appropriate sedimentary and hydrologic regimes occur. The most important paleoenvironmental conditions controlling the pattern of community replacement in this investigation therefore appear to include substrate texture and sedimentation rate.

The paleoecologic investigations of Haywick (1990) and Abbott \& Carter (1997) on New Zealand Pliocene-Pleistocene sequences have each related the occurrence of macrofaunal associations to recurrent stratal positions within sedimentary sequences. These examples are summarised in Fig. 8, together with the observed stratigraphic occurrences of Matemateaonga Formation biofacies. Despite the different ages of each of these examples of biofacies, they show marked similarities in faunal composition (at genus level). For instance, onlap shellbeds (basal transgressive sediment-bypassed lags) typically comprise Tawera-dominated faunas, whereas backlap shellbeds (late transgressive sediment-starved shell concentrations) contain Ostrea and glycymerid-dominated assemblages. Just as variation in sedimentologic and hydrologic regimes controls sequence architecture, such physical environmental factors also control the nature of a sequence's enclosed biofacies. Most macrofaunal associations identified by Abbott \& Carter (1997) are distinctive from those recognised in older cyclothemic facies, reflecting broad paleoenvironmental differences between middle Pleistocene (Castlecliffian) Wanganui Basin, and late Pliocene to early Pleistocene (Nukumaruan) and older cyclothemic facies of the Wanganui and East Coast Basins.

\section{Transgressive systems tract}

During transgressions, little net siliciclastic sedimentation occurred in shelf environments of the late Miocene to early Pliocene Wanganui Basin. Infaunal communities may have formed during periods of episodic sedimentation. Evidence for this includes the relative thickness of TST facies relative to those accumulated during HSTs and RSTs, and the taphonomy of densely packed shellbeds in which they are preserved, which suggests their remains were concentrated by processes of successive exhumation and winnowing processes 


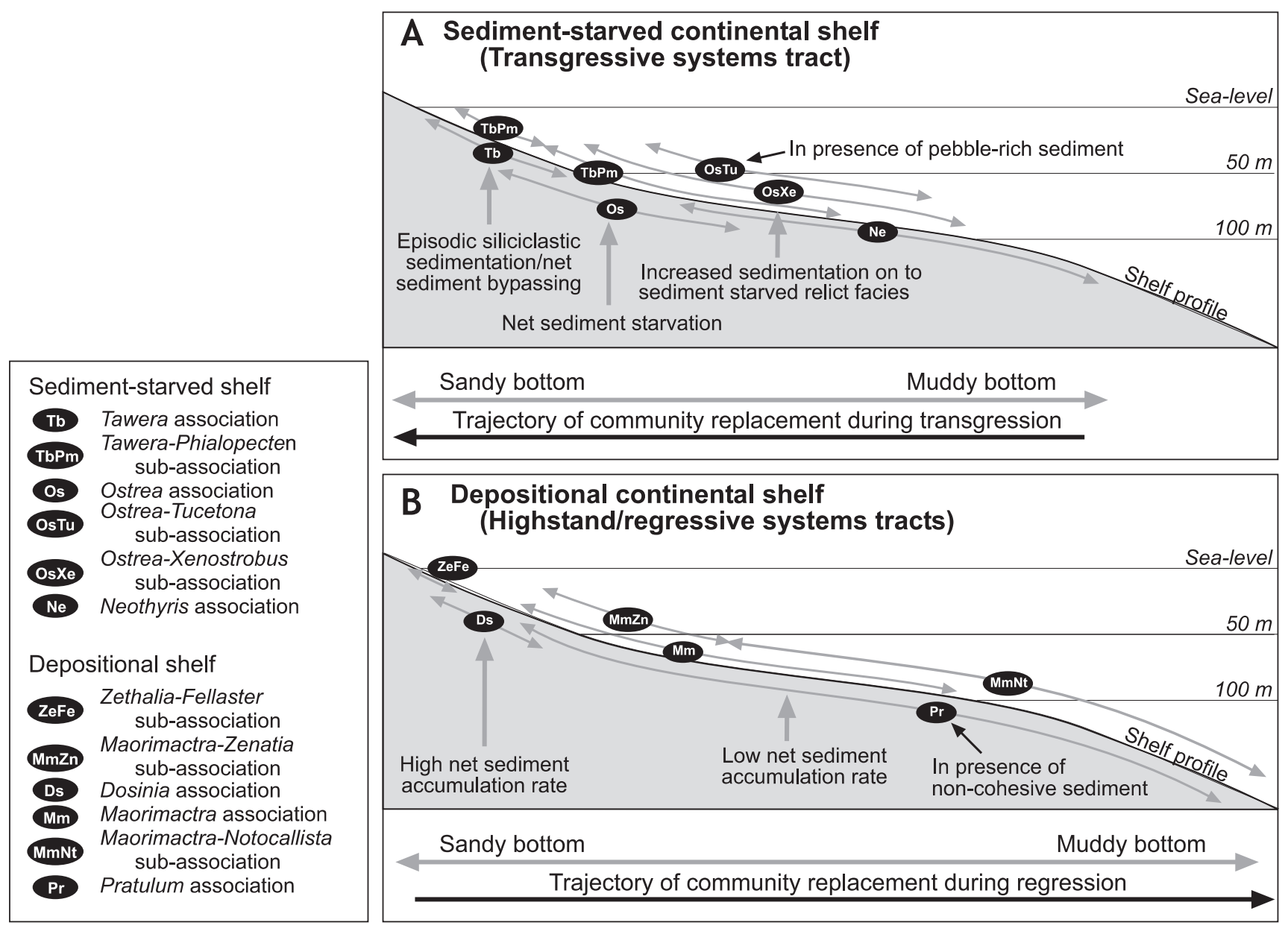

Fig. 7 Inferred distribution of biofacies on: (A) sediment starved (TSTs); and (B) high-sedimentation shelf environments (HST/RSTs).

(Hendy et al. in prep.). With continued moderate to high wave or current activity, this led to the formation of hardground or firmground substrates, which, in turn, were colonised by a predominantly suspension-feeding epifauna.

TSTs of the Matemateaonga Formation are characterised by highly time-averaged condensed deposits, essentially amalgamated multiple event beds. A combination of high energy and turbulence, and high sedimentation rates in innermost shelf settings, allowed for a recurring pattern of exhumation of infaunal communities, winnowing and burial of skeletal material, and subsequent recolonisation by similar communities. In most cases in the Matemateaonga Formation, the Tawera association represents these communities. As deepening continued, sedimentation rates decreased and epifaunal taxa became more dominant. The Ostrea-dominated and Tawera-Phialopecten associations are examples of fauna that became more abundant towards the end of transgressive periods. The proportion of individuals of epifaunal taxa in skeletal assemblages typically increases upwards within most TSTs as a result of the successive colonisation of firmgrounds of winnowed skeletal material by taxa such as Ostrea chilensis, Xenostrobus altijugatus, Phialopecten marwicki, and brachiopods.

\section{Highstand and regressive systems tracts}

During late highstand and in particularly regressive phases, net sedimentation rates are typically higher in offshore settings and the influx of land-derived nutrients potentially increased (Kamp \& Naish 1998). Thus, soft organic-rich substrates become available (Brett 1998). Sediments of the HST in the Matemateaonga Formation are composed predominantly of poorly fossiliferous massive sandy siltstone and fine-grained sandstone. Skeletal material within these successions generally comprises the remains of infaunal organisms, including shallow-burrowing suspension and deposit feeders. The most common taxa in these environments were members of the Pratulum and Maorimactra associations and sub-associations. These are preserved in situ by rapid burial and as storm-winnowed shellbeds (relatively high ecologic fidelity), which occur sporadically throughout the stratigraphic succession.

As the rate of relative sea-level fall increases, marking the onset of accumulation of the RST, shelf paleoenvironments are subjected to increased physical disturbance through wave and current erosion and increased turbidity (Brett 1998). This change in physical condition is therefore reflected in a change in faunal composition. Members of the Dosinia and Maorimactra-Zenatia association, which are adapted to living in such disturbed habitats, become more common higher in the stratigraphic succession that accumulates during highstand and falling sea-level phases. Areas of the shelf closest to shoreline (i.e., innermost shelf and shoreface environments) are represented by sediments accumulated during the latest portions of HST and RST. Shoreface to innermost shelf 


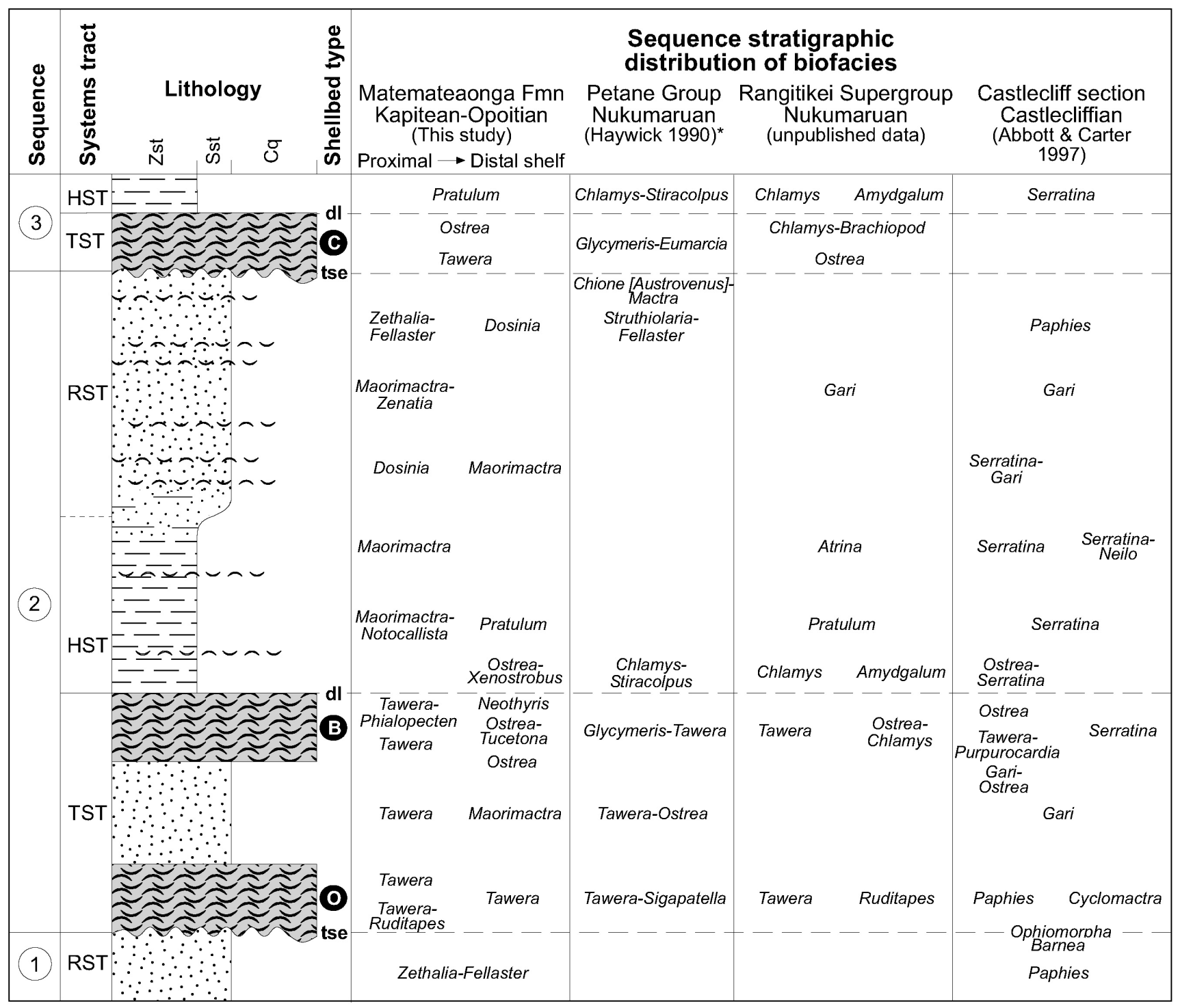

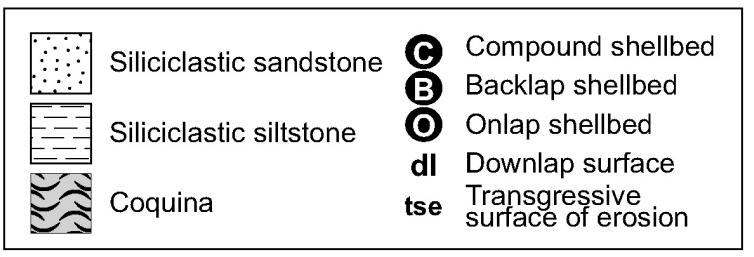

sediments include horizontally and cross-bedded sandstone, which contains members of the Zethalia-Fellaster and Tawera associations.

\section{SUMMARY AND CONCLUSIONS}

From an analysis of faunal compositional data, 15 macrofaunal associations and sub-associations have been defined from the Matemateaonga Formation in TongaporutuanOpoitian age sediments. These biofacies have been related to paleoenvironmental conditions on the basis of the environmental tolerances of their extant member taxa, comparison to closely related modern taxa, similar modern
Fig. 8 Predicted stratigraphic occurrence of biofacies within an idealised Matemateaonga Formation sequence and comparison with other studies: Petane Group (*data interpreted from Haywick 1990); Rangitikei Group (unpubl. data); and Castlecliff section (Abbott \& Carter 1997). benthic communities, and, to a lesser degree, analysis of associated sedimentologic and taphonomic features. The temporal and spatial distributions of these biofacies are largely controlled by availability of appropriate substrates, sedimentation rate, and turbulence, which are physical conditions that can be broadly correlated to water depth (onshore-offshore gradients).

These associations also show strong similarities to biofacies identified in younger sedimentary strata and the modern marine benthic environment of New Zealand in terms of their generic composition. This suggests high ecologic fidelity for many assemblages preserved in the Matemateaonga Formation to their original community structure, particularly in HSTs and RSTs, where the taphonomic characteristics of 
assemblages indicate little or no time averaging. Faunas of the TST, however, are typically environmentally condensed or at least time-averaged within habitat, and hence are more difficult to relate to modern benthic communities or to the establishment of accurate paleoenvironmental tolerances.

The cyclic and stratigraphically consistent changes in biofacies observed throughout sedimentary sequences of the Matemateaonga Formation reflect long-term (c. 41000 yr) variation in paleoenvironmental conditions, such as sediment flux, substrate nature, and wave and current action. Although not a perfect record, either because of erosion of strata during marine transgression, or non-preservation of benthic communities, a broad pattern of biofacies replacement can be observed. The stratigraphic distribution of these biofacies reflects the recurrence of discrete paleoenvironmental conditions at a particular site during specific portions of relative sea-level oscillations and particular paleogeographic conditions. As these associations occur in a consistent order and/or position within sedimentary sequences, it can be assumed that the patterns are caused by the shifting of biofacies belts or patches across the continental shelf during marine transgression or regression.

During early phases of transgression, the nearshore environment was characterised by episodic sand deposition (during an interval of net sediment deprivation) and the development of benthic communities dominated by shallowburrowing bivalves (Tawera-dominated associations). Towards the end of transgressive phases, away from nearshore sources of sediment influx, time-averaged shellgravels dominated the inner to mid shelf. Suspension-feeding epifauna-dominated benthic communities (Neothyris and Ostrea-dominated associations) spread over areas of the shelf starved of siliciclastic sediment at the expense of predominantly infaunal communities.

During early highstand conditions, increased fine-grained siliciclastic sedimentation overwhelmed epifauna-dominated communities, and allowed the colonisation of a dense, gregarious deposit and suspension feeding infauna (Pratulum and Maorimactra-dominated associations). Increasing coarsegrained siliciclastic sedimentation, wave and current energy, and turbidity during the course of sea-level highstand and subsequent regression resulted in a gradual replacement of benthic communities. Late highstand and regressive sediments are dominated by benthic communities of rapid-burrowing infaunal bivalves, gastropods, and echinoderms (Dosinia and Zethalia-Fellaster associations).

Several implications arise from this investigation. Firstly, the paleoecologic description of late Miocene to early Pliocene macrofaunal associations provides baseline data for the paleoenvironmental analysis of coeval rocks elsewhere in New Zealand. Secondly, paleoecologic data provided by biofacies analyses can be applied to understanding the paleoenvironmental changes associated with high-frequency eustatic sea-level oscillations in sedimentary basins of this age. Information on the scale of environmental change, such as variation in relative sea level and the rates of sediment flux, can be gained from analysis of biofacies distribution in relation to sequence stratigraphic marker beds. Finally, this analysis provides baseline data which allow for comparisons to be made between the predicted versus observed patterns of biofacies occurrence in sedimentary successions of differing age from basins preserving cyclothemic strata. These comparisons are of significance to studies of evolutionary paleoecology, but also yield evidence, in addition to sedimentary and taphonomic information, of subtle differences in basin sedimentologic and hydrologic regimes.

\section{ACKNOWLEDGMENTS}

We gratefully acknowledge Alan Beu for assistance with identification of macrofauna, and Bruce Hayward for guidance with statistical analyses. We sincerely thank Adam Vonk for provision of the stratigraphic context for the eastern Taranaki Peninsula part of this work and for the collection of some of the bulk samples. We thank NIWA for the provision of modern benthic sample data, and Scott Nodder for facilitating these data. We are grateful to Shaun Hayton, Laurence Gaylor, and Paul Haitana for field assistance on the Wanganui River section. Carlton Brett and David Meyer are thanked for critical suggestions during manuscript preparation. The manuscript was reviewed by Jack Grant-Mackie and Susan Kidwell, who provided much useful and constructive feedback. We acknowledge the New Zealand Foundation for Research, Science and Technology for funding support (UOW607 and UOWX0301). Funding (to AJWH) was also provided by the Hastie Award (Geological Society of New Zealand) and is gratefully acknowledged.

\section{REFERENCES}

Abbott, S. T.; Carter, R. M. 1997: Macrofossil associations from mid-Pleistocene cyclothems, Castlecliff section, New Zealand: implications for sequence stratigraphy. Palaios 12: $188-210$.

Beu, A. G.; Maxwell, P. A.; Brazier, R. C. 1990: Cenozoic Mollusca of New Zealand. New Zealand Geological Survey Paleontological Bulletin 58.

Brett, C. E. 1998: Sequence stratigraphy, paleoecology, and evolution: biotic clues and responses to sea level fluctuations. Palaios 13: 241-262.

Brook, F. J.; Grace, R. V. 1981: Soft-bottom benthic faunal associations of Tutukaka Harbour, Northland, New Zealand-Part 1 Macrofauna. Tane 27: 69-90.

Chauvand, L.; Jean, F.; Ragueneau, O.; Thouzeau, G. 2000: Longterm variation of the Bay of Brest ecosystem: benthic-pelagic coupling revisited. Marine Ecology Progress Series 200: 35-48.

Christie, A. B. 1973: Wilkies Shellbed, paleontology, sedimentology, and paleoenvironmental interpretation. Unpublished BSc (Hons) thesis, lodged in the Library, Victoria University of Wellington, Wellington, New Zealand.

da Montaudouin, X.; Audemard, C.; Labourg, P. J. 1999: Does the slipper limpet (Crepidula fornicata, Linné 1758) impair oyster growth and zoobenthos biodiversity? A revisited hypothesis. Journal of Experimental Marine Biology and Ecology 235: 105-124.

Dell, R. K. 1951a: Some animal communities of the sea bottom from Queen Charlotte Sound, New Zealand. New Zealand Journal of Science and Technology B33: 19-29.

Dell, R. K. 1951b: A molluscan fauna from the Mernoo Bank, New Zealand: New Zealand Journal of Science and Technology B33: 15-18.

Dodd, J. R.; Stanton Jr, R. J. 1981: Paleoecology, concepts and applications. New York, John Wiley and Sons.

Ehrhold, A.; Blanchard, M.; Auffret, J. P.; Garlan, T. 1998: The role of Crepidula proliferation in the modification of the sedimentary tidal environment in Mont-Saint Michel Bay (The Channel, France). Comptes Rendus de la Academie des Sciences serie II fascicule A-sciences de la terre et des planetes 327: 583-588. 
Estcourt, I. N. 1967: Distributions and associations of benthic invertebrates in a sheltered water soft-bottom environment (Marlborough Sounds, New Zealand). New Zealand Journal of Marine and Freshwater Research 1: 352-370.

Fleming, C. A. 1952: A Foveaux Strait oyster-bed. New Zealand Journal of Science and Technology B34: 73-85.

Fleming, C. A. 1953: The geology of Wanganui Subdivision. New Zealand Geological Survey Bulletin 52.

Gilinksy, N. L.; Bennington, J. B. 1994: Estimating numbers of whole individuals from collections of body parts; a taphonomic limitation of the paleontological record. Paleobiology 20: 245-258.

Grace, A. B. 1974: The palaeoecology of the Rapanui shell beds. Tane 20: 182-189.

Grace, R. V. 1966: The bottom communities of the entrance to the Whangateau Harbour. Tane 12: 63-70.

Grace, R. V.; Hayward, B. W. 1980: The macrobenthos of the Cavalli Islands, northern New Zealand. Tane 20: 189-209.

Grace, R. V.; Whitten, R. F. 1974: Benthic communities west of Slipper Island, north-eastern New Zealand. Tane 20: 4-20.

Grant-Mackie, J. A. 1990: Stacking and substrate preservation in a New Zealand Pliocene Crepidula (Mesogastropoda). In: Boucot, A. J. ed. Biotic interactions in Recent and fossil benthic communities. New York, Plenum Press. Pp. 195-248.

Hayward, B. W.; Grace, R. V. 1981: Soft bottom macrofauna and foraminiferal microfauna off Cuvier Island, north-east New Zealand. Tane 27: 43-54.

Hayward, B. W.; Grace, R. V.; Brook, F. J. 1981: The soft-bottom macrofaunal communities of the eastern Bay of Islands, northern New Zealand. Tane 27: 103-122.

Hayward, B. W.; Grace, R. V.; Bull, V. H. 1984: Soft-bottom macrofauna, foraminifera and sediments off the Chickens Island, northern New Zealand. Tane 30: 141-164.

Hayward, B. W.; Grace, R. V.; McCallum, J. 1986: Soft bottom macrobenthos and sediments off the Broken Islands, northern New Zealand. Tane 31: 85-103.

Hayward, B. W.; Blom, W.; Morley, M.; Stephenson, A. B.; Hollis, C. J. 1994: Benthic ecology of Whangape Harbour, Northland. Records of the Auckland Institute and Museum 31: 219-230.

Haywick, D. W. 1990: Stratigraphy, sedimentology, paleoecology and diagenesis of the Petane Group (Plio-Pleistocene) in the Tangoio Block, central Hawke's Bay, New Zealand. Unpublished PhD thesis, lodged in the Library, James Cook University of North Queensland, Australia.

Haywick, D. W.; Henderson, R. A. 1991: Foraminiferal paleobathymetry of Plio-Pleistocene cyclothemic sequences, Petane Group, New Zealand. Palaios 6: 586-599.

Hendy, A. J. W. 2003: Paleontology and sequence stratigraphy of the Matemateaonga Formation, Wanganui Basin, New Zealand. Unpublished MSc thesis, lodged in the Library, University of Waikato, Hamilton, New Zealand.

Holland, S. M. 1995: The stratigraphic distribution of fossils. Paleobiology 21: 92-109.

Jones, B. G. 1967: The geology and paleoecology of the Waipipian rocks of the Haweran coast. Tane 11: 61-68.

Kamp, P. J. J.; McIntyre, A. P. 1998: The stratigraphic architecture of late Pliocene (2.8-2.4 Ma) asymmetrical shelf sequences, western Wanganui Basin (New Zealand). Sedimentary Geology 122: 53-67.

Kamp, P. J. J.; Naish, T. R. 1998: Forward modelling of the sequence stratigraphic architecture of shelf cyclothems: application to late Pliocene sequences, Wanganui Basin (New Zealand). Sedimentary Geology 116: 57-80.
Kamp, P. J. J.; Vonk, A. J.; Bland, K. J.; Griffin, A. G.; Hayton, S.; Hendy, A. J. W.; McIntyre, A. P.; Nelson, C. S.; Naish, T. R. 2002: Megasequence architecture of Taranaki-WanganuiKing Country Basins and Neogene progradation of two continental margin wedges across western New Zealand. New Zealand Petroleum Conference Proceedings, 24-27 February 2002. Wellington, Crown Minerals, Ministry of Economic Development. Pp. 464-481.

Kamp, P. J. J.; Vonk, A. J.; Bland, K. J.; Hansen, R. J.; Hendy, A. J. W.; McIntyre, A. P.; Ngatai, M.; Cartwright, S. J.; Hayton, S.; Naish, T. R.; Nelson, C. S. 2004: Neogene stratigraphic architecture and tectonic evolution of Wanganui, King Country, and eastern Taranaki Basins. New Zealand Journal of Geology and Geophysics 47: 625-644 (this issue).

Kennedy, V. S.; Newell, R. I. E.; Eble, A. F. 1996: The eastern oyster Crassostrea virginica. College Park, Maryland, Maryland Sea Grant College.

Kidwell, S. M. 1991: Condensed deposits in siliciclastic sequences: expected and observed features. In: Einsele, G.; Ricken, W.; Seilacher, A. ed. Cycles and events in stratigraphy. Heidelberg, Germany, Springer-Verlag. Pp. 682-695.

Kidwell, S. M.; Bosence, D. W. J. 1991: Taphonomy and timeaveraging of marine shelly faunas. In: Alison, P. A.; Briggs, D. E. G. ed. Taphonomy: releasing the data locked in the fossil record. New York, Plenum Press. Pp. 115-209.

Kidwell, S. M.; Holland, M. 1991: Field descriptions of coarse bioclastic facies. Palios 6: 426-434.

Kidwell, S. M.; Jablonski, D. 1983: Taphonomic feedback: ecological consequences of shell accumulation. In: Tevesz, J. S.; McCall, P. L. ed. Biotic interactions in Recent and fossil benthic communities. New York, Plenum Press. Pp. 195-248.

King, P. R.; Thrasher, G. P. 1996: Cretaceous-Cenozoic geology and petroleum systems of the Taranaki Basin, New Zealand. Institute of Geological \& Nuclear Sciences Monograph 13.

Kirby, M. X. 2000: Paleoecological differences between Tertiary and Quaternary Crassostrea oysters, as revealed by stable isotope schlerochronology. Palaios 15: 132-141.

Kirby, M. X.; Soniat, T. M.; Spero, H. J. 1998: Stable isotope schlerochronology of Pleistocene and Recent oyster shells (Crassostrea virginica). Palaios 13: 560-569.

Kovach, W. L. 1999: MVSP - a multivariate statistical package for windows, version 3.1. Pentraeth, Wales, Kovach Computing Services.

Laws, C. R. 1950: Additional Lower Pliocene Mollusca from Otahuhu, Auckland. New Zealand Geological Survey Paleontological Bulletin 17: 1-35.

Luckens, P. A. 1972: Distribution of Nemocardium (Pratulum) pulchellum (Gray, 1843) (Mollusca: Bivalvia: Cardiidae) in the New Zealand region. New Zealand Oceanographic Institute Record 1: 47-63.

McIntyre, A. P. 2001: Geology of the Late Pliocene Mangapanian Stage, Wanganui Basin: chronology, paleontology and sequence stratigraphy. Unpublished $\mathrm{PhD}$ thesis, lodged in the Library, University of Waikato, Hamilton, New Zealand.

McKnight, D. G. 1969a: Infaunal benthic communities of the New Zealand continental shelf. New Zealand Journal of Marine and Freshwater Research 2: 409-434.

McKnight, D. G. 1969b: An outline distribution of the New Zealand shelf fauna; benthos survey, station list, and distribution of the Echinoidea. New Zealand Oceanographic Institute Memoir 47.

McKnight, D. G. 1974: Benthic faunas from the continental shelf, west coast North Island, Kawhia Harbour to Cape Terawhiti. New Zealand Oceanographic Institute Summary 4. 
Marwick, J. 1948: Lower Pliocene Mollusca from Otahuhu, Auckland. New Zealand Geological Survey Paleontological Bulletin 16.

Miller, W. II; Dubar, J. R. 1988: Community replacement of a Pleistocene Crepidula biostrome. Lethaia 21: 67-78.

Mitchell, L.; Curry, G. B.; Fallick, A. E. 1995: Stable-isotope and amino acid profiles of the New Zealand giant Pliocene oyster Crassostrea ingens. Lethaia 28: 237-243.

Morton, J. E.; Miller, M. 1968: The New Zealand sea shore. London, Collins.

Naish, T. R.; Kamp, P. J. J. 1997a: High-resolution sequence stratigraphy of 6th order (41 ka) Plio-Pleistocene cyclothems, Wanganui Basin, New Zealand. Bulletin of the Geological Society of America 109: 978-999.

Naish, T. R.; Kamp, P. J. J. 1997b: Foraminiferal depth paleoeocology of late Pliocene shelf sequences and systems tracts, Wanganui Basin, New Zealand. Sedimentary Geology 110: 237-255.

Neall, V. E. 1970: Notes on the ecology and paleoecology of Neothyris, an endemic New Zealand brachiopod. New Zealand Journal of Marine and Freshwater Research 4: 117-125.

Neef, G. 1997: Stratigraphy, structural evolution, and tectonics of the northern part of the Tawhero Basin and adjacent areas, northern Wairarapa, North Island, New Zealand. New Zealand Journal of Geology and Geophysics 40: 335-358.

Olszewski, T. D.; Patzkowsky, M. E. 2001: Measuring recurrence of marine biotic gradients: a case study from the Pennsylvannian-Permian midcontinent. Palaios 16 444-460.
Patzkowsky, M. E.; Holland, S. M. 1999: Biofacies replacement in a sequence stratigraphic framework: Middle and Upper Ordovician of the Nashville Dome, Tennessee, USA. Palaios 14: 301-323.

Powell, A. W. B. 1937: Animal communities of the sea-bottom in Auckland and Manakau Harbours. Transactions of the Royal Society of New Zealand 66: 354-401.

Powell, A. W. B. 1979: New Zealand Mollusca. Auckland, Collins.

Rollins, H. B.; Carothers, M.; Donohue, J. 1979: Transgression, regression, and fossil community succession. Lethaia 12: 89-104.

Scott, R. W. 1974: Bay and shoreface benthic communities in the Lower Cretaceous. Lethaia 7: 315-330.

Spratt, P. R. 1974: The stratigraphy and paleoecology of the Kaawa Formation. Unpublished MSc thesis, lodged in the Library, University of Auckland, Auckland, New Zealand.

Springer, D. A.; Flessa, K. W. 1996: Faunal gradients in surface and subsurface shelly accumulations from a recent clastic tidal flat, Bahia la Choya, northern Gulf of California, Mexico. Palaeogeography, Palaeoclimatology, Palaeoecology 126: 261-279.

Vonk, A. J.; Kamp, P. J. J.; Hendy, A. J. W. 2002: Outcrop to subcrop correlations of late Miocene-Pliocene strata, eastern Taranaki Basin. New Zealand Petroleum Conference Proceedings, 24-27 February 2002. Wellington, Crown Minerals, Ministry of Economic Development. Pp. 234-255.

Whitten, R. F. 1973: The Waipipian stratigraphy and paleoecology of the South Taranaki Coast. Unpublished MSc thesis, lodged in the Library, University of Auckland, Auckland, New Zealand.

Appendix 1 Bathymetric range data for extant taxa referred to in text and Fig. 3. Data assembled primarily from NIWA benthic sample data $^{1}$ (restricted to depths $<200 \mathrm{~m}$ ) and published faunal data (Brook \& Grace 19812; Dell 1951a ${ }^{3}, \mathrm{~b}^{4}$; Grace \& Hayward 19805; Hayward \& Grace 19816 ; Hayward et al. 19817 $, 1984^{8}, 1986^{9}$ ).

\begin{tabular}{|c|c|c|c|c|}
\hline Taxon & $\begin{array}{l}\text { Explanation for } \\
\text { use/reliability }\end{array}$ & $\begin{array}{l}\text { Range of greatest } \\
\text { abundance }(\mathrm{m})\end{array}$ & Total range $(\mathrm{m})$ & References \\
\hline Tucetona laticostata (Quoy \& Gaimard) & Extant & $20-80$ & $0-200(n=57)$ & $1,4,5,9$ \\
\hline $\begin{array}{l}\text { Modiolus areolatus (Gould) } \\
\text { (proxy for X. altijuagtus) }\end{array}$ & $\begin{array}{l}\text { Morphologically } \\
\text { similar/poor }\end{array}$ & $20-90$ & $0-130(n=45)$ & $1,3,4,6$ \\
\hline Ostrea chilensis & Extant & $0-80$ & $0-130(n=175)$ & 1,3 \\
\hline $\begin{array}{l}\text { Pratulum pulchellum } \\
\text { (proxy for } P . \text { finlayi) }\end{array}$ & $\begin{array}{l}\text { Similar extant } \\
\text { form/good }\end{array}$ & $10-150$ & $0-200(n=386)$ & $1,2,3,4,5,8$ \\
\hline $\begin{array}{l}\text { Maorimactra ordinaria } \\
\text { (proxy for } M . \text { chrydaea) }\end{array}$ & $\begin{array}{l}\text { Similar extant } \\
\text { form/good }\end{array}$ & $20-70$ & $0-160(n=82)$ & 1,2 \\
\hline $\begin{array}{l}\text { Oxyperas elongata } \\
\text { (proxy for O. komakoensis) }\end{array}$ & $\begin{array}{l}\text { Similar extant } \\
\text { form/good }\end{array}$ & $20-80$ & $10-130(n=11)$ & 1,5 \\
\hline Zenatia acinaces & Extant & $10-60$ & $0-130(n=136)$ & 1,8 \\
\hline Dosinia (Kereia) greyi & Extant & $10-50$ & $10-60(n=19)$ & 1 \\
\hline $\begin{array}{l}\text { Notocallista multistriata } \\
\text { (proxy for N. makoensis) }\end{array}$ & $\begin{array}{l}\text { Similar extant } \\
\text { form/good }\end{array}$ & $50-160$ & $0-200(n=180)$ & $1,3,5,8,9$ \\
\hline Ruditapes largillierti & Extant & $0-20$ & $0-140(n=30)$ & $1,5,8$ \\
\hline $\begin{array}{l}\text { Tawera spissa } \\
\quad \text { (proxy for } T \text {. bartrumi) }\end{array}$ & $\begin{array}{l}\text { Similar extant } \\
\text { form } / \text { good }\end{array}$ & $0-50$ & $0-200(n=180)$ & $1,2,3,4,5,8,9$ \\
\hline $\begin{array}{l}\text { Stiracolpus spp. } \\
\text { (proxy for Stiracolpus spp.) }\end{array}$ & $\begin{array}{l}\text { Extant spp. of } \\
\text { genus/good }\end{array}$ & $0-30$ & $0-200(n=111)$ & $1,2,5,7,8,9$ \\
\hline Zeacolpus vittatus & Extant & $20-110$ & $10-200(n=36)$ & 1,8 \\
\hline $\begin{array}{l}\text { Crepidula spp. } \\
\text { (proxy for } C \text {. radiata) }\end{array}$ & $\begin{array}{l}\text { Extant spp. of } \\
\text { genus/poor }\end{array}$ & $10-30$ & $0-200(n=18)$ & $1,2,3,8$ \\
\hline $\begin{array}{l}\text { Neothyris spp. } \\
\quad \text { (proxy for } N \text {. sp.) }\end{array}$ & $\begin{array}{l}\text { Extant spp. of } \\
\text { genus/good }\end{array}$ & $70-130$ & $10-200(n=55)$ & 1 \\
\hline
\end{tabular}

